\title{
Methods for rearing ground-nesting bees under laboratory conditions
}

\author{
Ryan J. LeONARD, Alexandra N. HARMON-ThrEATt \\ Department of Entomology, University of Illinois Urbana-Champaign, Urbana, IL 61801, USA
}

Received 15 March 2019 - Revised 21 June 2019 - Accepted 15 July 2019

\begin{abstract}
Ground-nesting bees are largely undervalued, both in terms of their use as model species for behavioural studies, and in terms of their agricultural benefit as pollinators in crop systems. But, why? One potential barrier limiting their use as model species may be our understanding of how to effectively establish and maintain groundnesting bees in the laboratory. Here we review how artificial nests are used to study ground-nesting bees and provide guidelines for building, starting and maintaining artificial nests. Ultimately, appropriate design and maintenance of artificial nests will allow researchers to explore a suite of interesting questions related to this important group of pollinating insects, from natural history to the origins of eusociality and the effects of environmental contaminants.
\end{abstract}

ground-nesting bee / artificial nest / rearing / Lasioglossum

\section{INTRODUCTION}

For over a century, artificial nests have formed a cornerstone of research efforts to understand the behaviour of bees. Indeed, the oldest definitive example of artificial nest use dates between 3000 $\mathrm{BCE}$ and 500CE, when humans first provided honey bees with artificial nest cavities (Kritsky 2010). Whilst especially common in managed species (e.g. Apis mellifera), artificial nest use is also increasingly employed to study populations of wild bees (Bosch and Kemp 2005; Moroń et al. 2012; Fortel et al. 2016). To date, artificial nest use in wild bees has largely been restricted to above-ground, cavity nesting species, a group that comprise less than $15 \%$ of the estimated 20,000

Electronic supplementary material The online version of this article (https://doi.org/10.1007/s13592-019-00679-8) contains supplementary material, which is available to authorized users.

Corresponding author: R. Leonard, rj1@illinois.eduJ.

Leonard, rj1@illinois.edu

Manuscript editor: James Nieh bee species globally (Cane 1991; Michener 2000). The artificial nests used to study this group (termed nest boxes) typically contain a sheltered collection of few to several hundred nesting cavities composed of porous material (e.g. 15-20-cm wood, polystyrene blocks, stems or reeds) opened at one end (reviewed by MacIvor (2017)). In the same way nest boxes continue to facilitate the study and understanding of above-ground cavity nesting bees (Forrest and Thomson 2011; MacIvor and Packer 2015; Staab et al. 2018), artificial nests also stand to provide critical insight into the ecology of lesser studied ground-nesting bee species.

Much like their above-ground counterparts, artificial nest use in ground-nesting bees has varied considerably over time. Since their inception in the early 1900s, artificial nests for ground-nesting bees have evolved from rudimental soil-filled buckets (Malyshev 1925; Hartman 1943) (also summarised by Linsley et al. (1952)), to in situ field and laboratory observation nests where nest structure and behaviour could be observed (Michener et al. 1955; Batra 1964). Among the 
first examples of artificial nests are clay blocks constructed by Soviet entomologist S.I. Malyshev in 1925 to study the nesting biology of Anthophora acervorum (Malyshev 1925). Over time, researchers began constructing artificial nests in situ. To this end, researchers dug down beside field nests of species including Lasioglossum zephyrum, and installed glass 'windows' made of microscope slides and/or glass tubes (Michener et al. 1955). These glass windows allowed researchers to observe behaviours within the upper parts of the nest, a task previously impossible using soil or clay blocks. The growing need for researchers to view behaviours occurring deeper in the nest led to the construction of structures capable of holding whole nests in the laboratory. Such nests were essentially soil-filled cavities sandwiched between two sheets of glass or Perspex (Figure 1) that allowed researchers to observe entire within-nest activity (e.g. cell construction, brood provision and egg laying, and behavioural interactions within social nests). Artificial nests of this type were originally described by Batra (1964) and subsequently refined by Michener and Brothers (1971), Kamm (1974), Bell et al. (1974) and Greenberg (1982b). Although originally used to study L. zephyrum
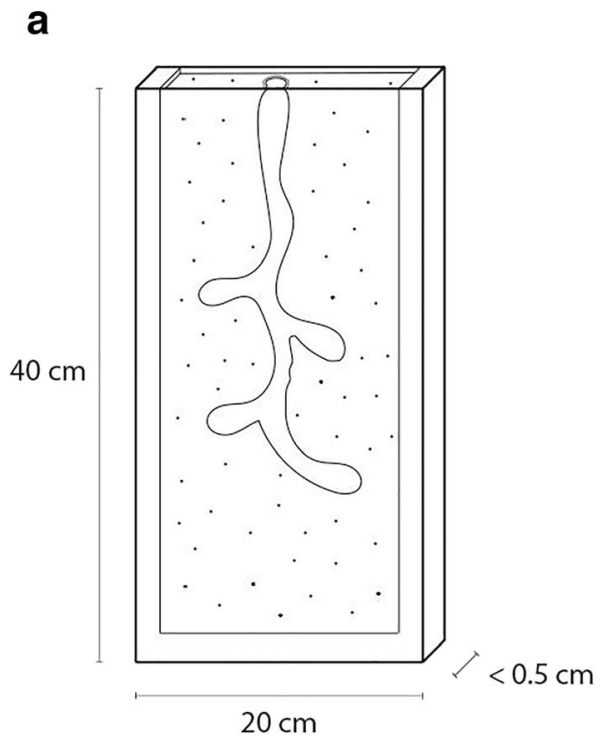

(see Batra (1964) and Michener and Brothers (1971)), they have also facilitated research on several additional species including L. hemichalceum (Jeanson et al. 2005), L. NDA1 (Holbrook et al. 2013) and Macrotera portalis (Danforth 1991a, b).

Despite advances in the design and experimental use of artificial nests, they remain an underutilised resource for studying fundamental behaviours including 'stress'-mediated ecological responses. Indeed, very few studies use artificial nests to investigate the effects of environmental stressors on developmental, behavioural and physiological phenotypes in ground-nesting bees (but see Kamm (1974)). Most studies on groundnesting bees instead quantify changes in forager abundance and diversity, along gradients of environmental stress or following field exposure to certain stressors (e.g. urbanization, agricultural practices, pollution) (Kim et al. 2006; Kearns and Oliveras 2009; Kratschmer et al. 2018). Whilst such studies provide novel ecological and conservation insight, the systematic use of artificial nests stands to afford a greater mechanistic understanding of stress-mediated ecological responses in this important group. This is especially relevant to discussions regarding the proposed

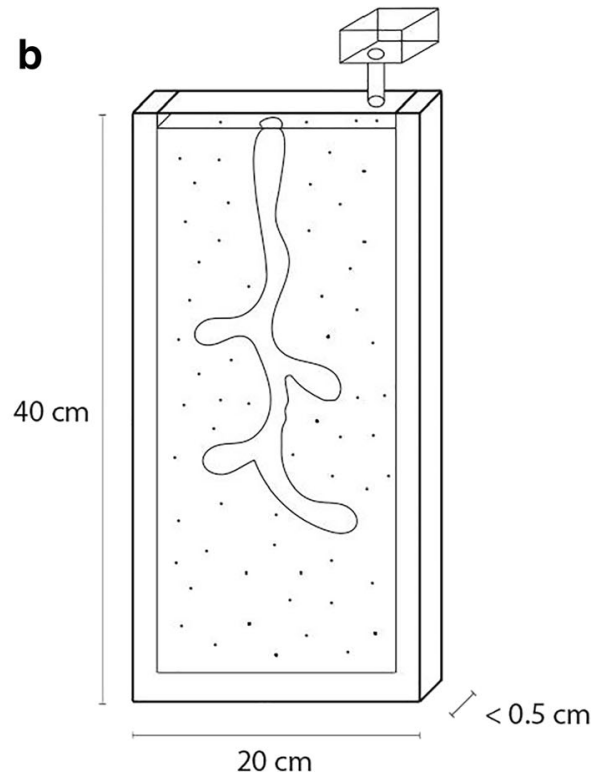

Figure 1. Schematic diagram of $\mathbf{a}$ open and $\mathbf{b}$ closed observation nest. 
suitability of ground-nesting bees as test organisms for regulatory decisions on pesticide approval (European Food Safety Authority 2013). Despite their proposed suitability, there are currently no widely accepted guidelines for laboratory studies and very limited information concerning semifield or field test methods (Ruddle et al. 2018).

The goal of this review is to aid researchers in constructing and maintaining artificial nests for ground-nesting bees. Having reviewed the literature on this group of pollinating insects (Supplementary Table 1), we summarise relevant considerations relating to the types of nests used and factors significantly affecting nesting success including nesting substrate, food provision and abiotic factors (e.g. temperature). We also explore strategies facilitating nest establishment in the laboratory, as well as colony and individual collection. Whilst this review will ultimately help in standardising the establishment and maintenance of artificial nests for ground-nesting bees, many of the techniques reviewed here may also be useful in the study of other understudied ground-nesting groups including wasps (e.g. Vespula sp.) and beetles (e.g. Cicindelinae and Scarabaeoidea sp.).

\section{ARTIFICIAL NEST TYPES}

\subsection{Open vs. closed observation nests}

Up until Kamm (1974), most studies conducted on ground-nesting bees in laboratories used open nests, whereby artificial nesting cavities had no lid (e.g. Michener and Brothers (1971)). These nests are created using two pieces of glass or Perspex, separated by plastic tubing and held together with clips (Figure 1). The nests are filled with soil and positioned vertically in an insectary where food resources (e.g. fresh cut flowers) can be provided to bees ad libitum. Whilst open nests remain useful for answering questions relating to sociality and basic nest building and provisioning behaviours (Batra 1964, 1968, 1970; Plateaux-Quénu 1992), they are limited in their ability to control for factors including which bees enter and leave nests, inter-nest behavioural interactions (e.g. potential effects of foragers from different nests encountering each other) and the amount of food collected by foragers. Closed nests ultimately provide more experimental control (i.e. limit confounding factors) and, when paired with careful experimental manipulations, will likely provide greater insight into ground-nesting bee physiology and responses to disturbances (e.g. disease, pesticide application, soil moisture).

Closed nests are constructed much like their open-nest counterparts, except plastic tubing is glued to the top of the nest to prevent bees from escaping (Figure 1). A short piece of additional tubing (e.g. 3-5-cm length, < 4-mm inside diameter) attached to a plastic container (e.g. $3 \mathrm{~cm}$ high and $3.5-\mathrm{cm}$ diameter) containing food is inserted into the top of the nest, allowing bees to feed (Kamm 1974). Bees maintained in closed observation nests do not appear to suffer adverse side effects attributed to the confined space. To date, closed nests have been used to effectively answer questions relating to within-nest interactions in social species including the effects of colony size on colony activity (Kukuk and May 1991), and queen-worker behaviour (Greenberg and Buckle 1981; Buckle 1982). They have also been employed in controlled dietary studies where response variables included development (Roulston and Cane 2002), and reproductive physiology (Kapheim and Johnson 2017).

\subsection{Field and greenhouse nests}

In addition to maintaining open and closed observation nests under laboratory conditions, researchers have also successfully established several ground-nesting bee species in the field (i.e. artificial bee beds) (Stephen 1960a; Ullmann et al. 2016), or more commonly, greenhouses (Stephen 1965; Bell et al. 2006; Hogendoorn et al. 2006; Schäffler and Dötterl 2011). Successfully established species include Amegilla (Zonamegilla) holmesi, Amegilla chlorocyanea, Macropis fulvipes, Peponapis pruinosa and N. melanderi (Supplementary Table 1). For $N$. melanderi, several protocols for creating bee beds in situ that facilitate successful propagation of this species have been described previously (Stephen 1960a). Artificial bee beds can include horse troughs (e.g. $245 \mathrm{~cm} \times 120 \mathrm{~cm}$ boxes), or pits (e.g. approx. $240 \mathrm{~cm} \times 365 \mathrm{~cm} \times 60 \mathrm{~cm}$ deep Stephen (1960a); $100 \mathrm{~cm}^{2} \times 50 \mathrm{~cm}$ deep Fortel 
et al. (2016)) lined with polyethylene sheets and a 5-10-cm gravel layer to facilitate drainage. Beds are backfilled with soil typically mixed with salt to enhance water retention properties (Stephen 1960b). Several pipes can also be inserted into the soil through which water can be introduced to maintain soil moisture.

Much like open observation nests, nests maintained in the field or greenhouses cannot control for several potentially confounding factors. Furthermore, unless whole nests are sacrificed (e.g. all individuals killed), response variables are limited to observations of above-ground behaviours. As such, nests established in fields or greenhouses are typically used to study the pollination services provided to crop species by ground-nesting bees. Effective pollination of tomato plants (Lycopersicon esculentum), for instance, was demonstrated in greenhouses containing maintained populations of $A$. holmesi (Bell et al. 2006) and A. chlorocyanea (Hogendoorn et al. 2006), two species of Australian blue banded bee.

Establishing colonies or aggregations of ground-nesting bees in the field could ultimately facilitate their collection and transferal to laboratory observation nests for further study, a worthy task given the difficulty in finding naturally occurring nests. Although philopatry is generally high in ground-nesting bees (Cane 1997), and certain species including Euglossa annectans did not abandon nests when given direct access to the field (Boff et al. 2017), we suspect nest abandonment will still likely be an issue in field experiments. Indeed, of 200 adult $N$. melanderi released into artificial beds in the field, only $6 \%$ nested successfully (Parker and Potter 1974).

\subsection{Male flight cages}

Depending on the question, a researcher may be required to maintain male ground-nesting bees under laboratory conditions for extended periods. In such cases, males can be kept in flight cages (Greenberg 1982a, b; Wcislo 1992) including net containers (e.g. $16 \times 12 \times 13 \mathrm{~cm}$ ) more typically used for breeding fish. Lasioglossum zephyrum males, for example, have successfully been kept in cages containing pollen and water ad libitum for several weeks (Greenberg 1982a). We do not anticipate male-male aggression to be a significant factor affecting male survival in such set-ups. Indeed, male-male aggression resulting in death may occur in some species, including $M$. portalis (Danforth 1991b), but most male-male encounters generally only involve grappling and lunging (Barrows 1976).

\section{DESIGN CONSIDERATIONS FOR OBSERVATION NESTS}

In the following sections, we review nest design considerations for open and closed observation nests, including artificial nest dimensions and the materials required to construct nests of ground-nesting bees.

\subsection{Artificial nest dimensions}

The maximum 'natural' nesting depths of ground-nesting bees vary greatly (Cane and Neff 2011). For example, the maximum field-observed nest depths recorded for species employed in laboratory (semi-laboratory) studies range from approximately $5 \mathrm{~cm}$ in M. portalis (Danforth 1991a) to more than $135 \mathrm{~cm}$ in L. versatum (Michener 1966). Rather than accommodate the maximum natural nesting depths observed in the field in laboratory studies, researchers commonly allocate bees to artificial nest cavities $40 \mathrm{~cm}$ deep (Michener and Brothers 1971). Certain species including L. hemichalceum have also successfully built nests in artificial nest cavities only $15 \mathrm{~cm}$ deep (Jeanson et al. 2005; Holbrook et al. 2013). The horizontal length of nest cavities does not appear to be an important factor influencing nesting success in the lab, with most boxes typically $20 \mathrm{~cm}$ across (Michener and Brothers 1971). Narrower nest cavities (i.e. $1.5 \mathrm{~cm} \times 15 \mathrm{~cm}$ ) may be worthwhile considering in future studies as they may increase the likelihood bees start nests and/or dig a single tunnel (Jeanson et al. 2005).

Arguably, the most important parameter pertaining to artificial nest cavity dimensions is the cavities' width (Batra 1968). A researcher must be capable of observing a bee's activities in the burrow and cells of the nest. For this reason, a nest's width should be equal to, or slightly smaller (e.g. $<1 \mathrm{~mm}$ ) than, the diameter of tunnels and 
cells found in natural nests in the field. 2Burrow and cell diameters do vary in the field and among species but are generally small. For example, burrows are between 0.95 and $1 \mathrm{~cm}$ in Epicharis albofasciata (Rozen 2016), $\sim 0.75 \mathrm{~cm}$ in Euglossa melanotricha (Andrade-Silva and Nascimento 2012) and $\sim 0.40 \mathrm{~cm}$ in L. zephyrum (Batra 1964). For species including L. versatum, L. imitatum and Augochlorella sp., Batra (1968) advocates an artificial nest diameter of between 0.30 and $0.35 \mathrm{~cm}$ which is approximately $1 \mathrm{~mm}$ less than the diameter of cells and burrows observed in the field. For Halictus rubicundus, a width of $5.00-5.50 \mathrm{~mm}$ is suitable (Batra 1968).

\subsection{Nesting materials}

Artificial observation nests are typically constructed using soil collected from nesting sites in the field (Michener and Brothers 1971; Barrows et al. 1975). The specific soil type used, however, is rarely identified in studies. This is surprising given nest site suitability and/or the propensity to construct nests may be related to soil characteristics including the percentage of organic matter, as well as, the amounts of sand, silt and clay (Cane 1991; Potts and Willmer 1997; Grundel et al. 2010). Furthermore, soil type may be important in cases where substrate can affect morphological traits such as mandible and wing wear which may be used as proxies for bee age (Stockhammer 1966; Dalmazzo and Roig-Alsina 2015). Whilst bees are unlikely to construct nests in clay or silt soils, they do nest in a diversity of soil types, ranging from sand to loam and silt loam (Cane 1991). Lasioglossum zephyrum and $N$. melanderi, two common species in laboratory studies, nest principally in loam clayey soil (Michener and Brothers 1971) and inorganic sandy or clayey soil (e.g. clay size particle content $<8 \%$ ) (Bohart 1955; Stephen 1960a) respectively. Several species including Ptiloglossa arizonensis, Caupolicana yarrowi, Xenoglossa angustior, Colletes thoracicus and Dialictus laevissimus also nest in soils of markedly different textures (Cane 1991). The extent to which soil texture may influence nesting propensity for most species, however, is unclear (Fortel et al. 2016). In addition to soil type and texture, properties including soil salinity, sodicity and mineral content may be important. The distribution of Eucera nigrilabris, for example, is positively associated with decreasing soil salinity, sodicity, and calcium carbonate content in the field (Shebl et al. 2016). Further studies are needed to clarify the effects of these soil properties on nesting behaviours.

Parasites including mites and nematodes may influence nesting success; as such, once soil is collected from the field, it should be freeze dried (Stockhammer 1966) or autoclaved (Roulston and Cane 2002). A large number of fungi (i.e. at least 124 species, Batra (1984)) may affect nesting success by infesting large portions of the nest and attacking adults and brood. In $N$. melanderi open observation nests, for example, $35 \%$ of cells may be contaminated with fungi including Aspergillus tamarii, Fusarium solani, Mucor sp. and Fusarium sp. (Batra 1970). Soil can be treated using fungicides before/ after nest construction (e.g. with methyl paraben; Roulston and Cane (2002), McFrederick and Taylor (2013)); however, caution should be taken as little is known regarding the ecological effects of these chemicals on bees (Kopit and Pitts-Singer 2018). A more appropriate method to limit fungal growth may involve ensuring soil moisture does not exceed certain thresholds including those required by bees. High soil moisture increases cell humidity, in turn permitting the germination of fungal spores. In $N$. melanderi, overly moist soil (i.e. $>20 \%$ moisture) leads to the replacement of overwintering pupae by fungal mycelia (Stephen 1965).

Whilst soil moisture increases the chance of fungal growth, it also plays a key role in nesting success for many ground-nesting species including L. zephyrum (Michener and Brothers 1971) and N. melanderi (Stephen 1960a, 1965). Alkali bees such as $N$. melanderi typically only nest in soils where moisture ranges from 15 to 25 centibars (Johansen et al. 1976). To ensure soil does not dry out, soil should be moistened regularly (e.g. daily). This task is made easier if the plastic tubing used to construct nests (i.e. the tubing between plexiglass sheets) is perforated with small holes and water added directly to the tubing when soil appears dry (Batra 1964). Alternatively, a thin layer (approx. $1.5 \mathrm{~cm}$ ) of plaster of Paris can be poured into the bottom of nests to hold moisture and 
maintain humidity (Stockhammer 1966). Ropes soaked in water jars can also be used to wick water to the soil (personal communication, Quinn McFrederick). Care should be taken to ensure soil does not become too moist, as emergence and mortality may be affected. In N. melanderi, soil moisture exceeding $10 \%$ is associated with lower adult emergence and significantly higher prepupae mortality (Stephen 1965). Furthermore, direct contact with water kills brood in L. zephyrum (Greenberg 1982b). As such, water should not be applied near cells with brood.

To facilitate packing into artificial nest cavities, soil can be broken up and sifted whilst slightly moist. Given bees do not readily establish in soil that is loosely packed (Michener and Brothers 1971), it may be necessary to compress soil using a rolling pin into the nesting cavity. Soil is typically compressed until tunnels can be cut into the soil using a razor blade (Danforth 1991a), or indentations (i.e. $1 \mathrm{~cm}$ ) can be made in the soil's surface. These techniques may encourage nest construction (Jeanson et al. 2005, 2008; Holbrook et al. 2009, 2013) and seem to work well for L. hemichalceum and L. NDA-1 (Jeanson et al. 2005). Artificial burrows and cells can also be created by pushing wire into the soil and then pressing plaster of Paris casts of naturally constructed cells into the soil next to these artificial burrows. Advanced pupae can then be placed into these artificial cells (Michener and Brothers 1971). The placement of pebbles or leaf material on the soil's surface may also encourage nesting building; $H$. rubicundus, for instance, prefer to nest amid pebbles, rather than bare dirt (Cane 2015).

\section{SEEDING ARTIFICIAL NESTS}

\subsection{How to collect individuals and excavate colonies}

Chief among the factors hindering the use of ground-nesting bees in laboratory studies is the difficulty in finding and collecting individuals from natural nesting areas and obtaining data from underground nests (Martins et al. 2014; Marinho et al. 2018). We suspect this factor at least in part explains taxonomic bias in the species used for laboratory studies. That is, most laboratory research on ground-nesting bees use species typically easier to find, including those forming colonies and/or those nesting in dense aggregations. Lasioglossum zephyrum, the subject of most manipulative studies on ground-nesting bees, for instance, is a social species nesting along bare, vertical river banks (Batra 1964; Breed et al. 1978). Similarly, Nomia melanderi, a similarly well-studied ground-nesting bee, forms large aggregations in soil beds near alfalfa seed fields (Cane 2008).

\subsection{Collecting individuals}

Techniques employed to collect individuals will vary depending on the species of interest and the ease with which nests can be located in situ. Given the nests of most ground-nesting species are cryptic, subtle and typically integrated with floral resources, they are difficult to find. As such, netting from known floral host species likely represents the most effective method for capturing individuals. In cases where nests can be located in the field, styrene cups may be placed over nest entrances or aspirators can be used to capture individuals leaving the nest. Several Lasioglossum species including L. malachurum (Strohm and Bordon-Hauser 2003) and L. zephyrum (Roulston and Cane 2002) were captured previously using these techniques. When collecting $N$. melanderi from nest entrances, we suspect researchers may have more success collecting from entrances whose associated mounds are small. Small compared with large mounds indicate the nest is newer (i.e. $1 / 2$ day old) and, therefore, more likely to contain bees (Bohart 1955). Species including L. hemichalceum, L. NDA-1, Ptilothrix plumata have also been captured by netting directly above known nest aggregations using sweep nets (Martins et al. 2001; Jeanson et al. 2005, 2008). Although potentially more time consuming, due to the frequency with which traps need to be checked, emergence traps placed on beds prior to initial emergence can also be used to capture ground-nesting bees. This technique has worked previously with $N$. melanderi when traps were placed over known nesting aggregations and checked three times daily (Kapheim and Johnson 2017). 
When directly collecting individuals, researchers should be wary of potential age and sex bias; for social species, individuals leaving the nest tend to be foragers which are female and older (Batra 1964). The age of collected individuals can be discerned by checking for certain morphological traits; worn mandibles in L. zephyrum for instance likely indicate an older worker (Michener et al. 1955). Wing wear may also represent a non-invasive method for discerning age in certain social and solitary species. Whilst this technique has been used as an age correlate in bumblebees (Bushmann et al. 2012), it is currently more commonly used to discern age in above-ground-nesting species (e.g. Anthidium manicatum, Mueller and Wolf-Mueller (1993)).

\subsection{Whole nest extraction}

Whilst extracting entire nests may be more labour intensive and destructive than collecting individuals directly, it has the advantage of potentially increasing the chance of capturing developing bees or, in the case of social species, individuals that normally remain within the nest (e.g. callows and primary egg-laying individuals). Nests can be extracted using either soil core sampling techniques (e.g. Stephen (1960a), Cane (2008), Donovan et al. (2010), Vinchesi and Walsh (2014)) or by allowing bees to colonise artificial nest blocks (e.g. buckets containing mud or clay) positioned near known nesting aggregations during spring and summer (e.g. Norden (1984), Graham et al. (2015), Davison and Field (2018a), Davison and Field (2018b), Supplementary Table 1). When soil cores are taken, the volume of soil collected will depend on the nesting dimensions of the focal species and the equipment available. In Leioproctus huakiwi, for example, soil cores of $4.5 \mathrm{~cm}^{3}$ were sufficient (Donovan et al. 2010). Contrastingly, in $N$. melanderi, soil cores of approximately $30 \mathrm{~cm}^{3}$ (Cane 2008) and $13,725 \mathrm{~cm}^{3}(15 \mathrm{~cm} \times$ $15 \mathrm{~cm} \times 61 \mathrm{~cm}$ depth) (Vinchesi and Walsh 2014) have been collected. In cases where the volume of soil collected is large, an electronic soil coring device connected to a backhoe powered by hydraulics may be needed (Vinchesi and Walsh 2014). Upon collection, soil cores or artificial nest blocks can be bagged and transported to the laboratory or elsewhere for further study or individual bee collection (e.g. Norden (1984), Schäffler and Dötterl (2011)). One disadvantage of taking soil cores is the potential destruction of some cells within the nest. This can be reduced by extending the diameter of the soil core taken or by using artificial nest blocks if appropriate. An additional technique used to extract whole colonies in the field (e.g. Augochlora amphitrite (Dalmazzo and Roig-Alsina 2012), L. malachurum (Paxton et al. 2002) and M. portalis (Danforth 1991b)) involves blowing a fine mist of talcum powder or plaster of Paris down into the tunnels, digging away at the soil and then collecting bees (e.g. Danforth (1991a, b), Dalmazzo and Roig-Alsina (2012)). Talcum powder is used to aid in tracing where the nests' tunnels and attached brood cells are.

\subsection{When to collect bees}

The optimal time of year and day to collect ground-nesting bees will depend on the focal species considered and method of collection (e.g. individual versus entire nest). Emergence time and activity can vary greatly between species; as such, researchers will need to consult species life histories prior to collection. As a general rule, species overwintering as adults ( $M$. rotundata) become active in spring ('spring bees') whilst those that finish metamorphosis after winter become active later in the season ('summer bees') (Fründ et al. 2013). Several species may also emerge in fall (e.g. Melissodes rustica) (Cameron et al. 1996). Species used in laboratory or field studies including Lasioglossum sp. (Batra 1968; Wcislo 1992), Halictus rubicundus (Potts and Willmer 1997) and N. melanderi (Batra 1970) are typically collected in the field from April through until July. Whilst L. zephyrum has also been collected in the fall and winter (i.e. inactive/overwintering period) (Batra 1968), prior knowledge of their exact location is needed owing to difficulty in finding nest locations when bees are inactive (Linsley et al. 1952). Whole nest extractions are best conducted early in the day, or on cloudy days when all resident bees are most likely present within the nest (Danforth 1991b). 


\section{STARTING OBSERVATION NESTS IN THE LABORATORY}

Once ground-nesting bees have been collected from the field, researchers typically establish observation nests for social species using either adult females (e.g. Kukuk and Crozier (1990)) or callows (e.g. Buckle (1982)). Further research is needed to determine the utility of adult females versus callows for nest establishment in solitary species. In social species, starting artificial colonies with adults generally fails more readily (Greenberg 1982b); however, researchers have had success using adults from several species including L. zephyrum (Roulston and Cane 2002), L. erythrurum (Kukuk and Schwarz 1987; Kukuk and Crozier 1990) and L. NDA-1 (Holbrook et al. 2013). Adults from the same colony (e.g. Kukuk and Decelles (1986)) or several different colonies (e.g. Kukuk and Crozier (1990)) (i.e. related or unrelated individuals) can be collected from the field and transferred directly into artificial nests. In L. zephyrum, for example, adults from 11 out of 16 field colonies successfully established laboratory colonies following individual extraction from the field (Kukuk and Decelles 1986).

The more common method used to start laboratory observation colonies using adults involves collecting mated females from field nests in late summer or early autumn, allowing these individuals to overwinter in the lab, and then waiting until individuals initiate their own nest the following spring (e.g. Batra $(1964,1968)$, Michener et al. (1971)). Allowing bees to overwinter in the lab helps establish philopatry and seems to encourage nesting under the same conditions. When establishing these nests, special care should be taken to ensure overwintered females of L. zephyrum, and related species (e.g. L. erythrurum and L. NDA-1), are not disturbed during the egg-laying period. In cases where individuals have not laid eggs by late spring, we suspect it unlikely these individuals will successfully establish laboratory nests.

High adult nesting failure commonly observed under laboratory conditions is likely attributed to the large degree of philopatry observed in groundnesting species generally (Cane 1997). In
H. rubicundus for example, foundress philopatry is so high that most nests are built within $50 \mathrm{~cm}$ (average $=27 \mathrm{~cm}, n=113$ ) of natal nests constructed the previous year (Yanega 1990). In addition to philopatry, disorientation following capture may be important in explaining adult nesting failure (Greenberg 1982b). High adult nesting failure has ultimately led to the more common use of callows when establishing laboratory nests (Greenberg 1982b).

When using callows to establish nests, overwintered pupae or newly emerged adult females are typically placed in 'pre-made' observation nests (e.g. Kumar (1975), Kukuk et al. (1977)). The number of individuals added to nests will vary depending on the research question asked and whether the species is solitary or social. In social species, 4 to 12 and more commonly 6 individuals are used for most species studied (Kamm 1974; Kukuk et al. 1977; Greenberg 1982b; Buckle 1984; Danforth 1991a). Following initial callow introduction, nest entrances can be plugged for several hours (e.g. overnight) to decrease the likelihood of nest abandonment (Greenberg 1982b). Researchers should not plug nests containing individuals older than 2 days as this will likely lead to suicide-tunnelling (Buckle and Greenberg 1981; Greenberg 1982b), a behaviour that may destroy laboratory observation nests. Suicide tunnelling occurs in social nests when bees dig tunnels without clearing away the excavated dirt, resulting in the suicide-tunneller losing contact with the nest, nestmates, food sources and ultimately dying within 1-2 days (Buckle and Greenberg 1981). Whilst this behaviour has been observed in individuals introduced into colonies from different source nests (Buckle and Greenberg 1981), the specific reasons why bees suicide tunnel, beyond nest rejection, are unknown. Aside from plugging nests, researchers can also increase the chance of nest establishment by introducing callows at night, when individuals are more reluctant to leave nests (Greenberg 1982b).

Once social nests containing callows are established, individuals should be inseminated to ensure colony longevity. For several social species, including L. zephyrum, inseminating only dominant individuals may be 
sufficient as these individuals typically become primary egg layers (i.e. queens). Dominant individuals or would-be-queens can be discerned by observing within-nest behaviours including nudging, being nudged, backing, following, passing, being passed, pollen collecting, working on burrows and working on cells (Michener and Brothers 1974). Alternatively, circle tube arenas made from sections (e.g. 30$40 \mathrm{~cm}$ ) of clear plastic tubing (usually polyethylene) and joined at the ends may be useful (see Breed et al. (1978), Kukuk and Decelles (1986), Polidori and Borruso (2012)). Compared with other bees, queens spend a significant proportion of their time exhibiting certain behaviours including nudging and backing (Michener and Brothers 1974; Breed and Gamboa 1977; Breed et al. 1978). Queens are also less likely to pass other bees (Michener 1974). It is best to mate females including queens within the first 2 weeks of their life (Greenberg 1982b). To this end, females can be introduced into flight cages (see above) containing 1-2 males. Upon introduction, males have been observed to mate with females almost immediately (Barrows 1975; Greenberg 1982b). For example, in a total of 56 matings observed in Augochlora pura, L. rohweri and L. zephyrum, $96.5 \%$ of mattings occurred in the first 2 min of presentation (Barrows 1975).

\section{BEE AND NEST MAINTENANCE CONSIDERATIONS}

\subsection{Food provision}

To sustain ground-nesting bees in the lab, researchers must adequately supply pollen and nectar sources, with adequacy largely dependent on species-specific protein and sugar requirements. With the exception of M. portalis, an oligolectic species of Sphaeralcea (Malvaceae) (Danforth 1991b), most species used in laboratory studies to date are generalist foragers which are typically easier to provision for consistently. Regarding the provision of non-host pollen to either oligolectic or generalist ground-nesting species, very little is currently known. Oligolectic above-groundcavity nesting species may suffer adverse consequences when reared on non-host pollen. Adults of the resin bee, Heriades truncorum, for example develop cognitive constraints when reared on non-host pollen (Praz et al. 2008). Depending on the research question asked, access to food can be achieved either through open foraging on provided flowers or through closed foraging on supplied sugar/honey water and loose pollen. Several studies on ground-nesting bees employ open nests and allow bees to forage on fresh cut or potted flowers in insectaries (e.g. Batra (1964), Brothers and Michener (1974), Sick et al. (1994), Dalmazzo and Roig-Alsina (2015)). Although the specific flower host species is rarely specified, Batra (1970) did find potted or freshly cut alfalfa mustard, Melilotus spp. and Cleome serrulate were the preferred pollen and nectar sources for $N$. melanderi under laboratory conditions.

The more common experimental set-up uses closed nests (see above) where Apis-honey or sugar water and pollen, generally from one pollen host species, is provided (e.g. Kamm (1974)). Given foraging bees cannot feed effectively on viscous mixtures, honey to water ratios of 50:50 (v:v) are generally used (Bell 1973). If the honeywater mixture is too dilute, it fouls quickly, therefore needing replacement regularly. Furthermore, honey water that is not replaced regularly will ferment and may be picked up by foragers' feet, transferred to pollen, in turn facilitating mould growth (Greenberg 1982b). Typha (common name: Cattail; genus containing 30 species) is by far the most common pollen host genera provided to bees (Kamm 1974), and Typha latifolia the most common pollen host species (species rarely identified but see Roulston and Cane (2002)). The pollen of T. latifolia is anemophilous, and therefore high in starch content (i.e. $14.5 \%$ starch, $17 \%$ protein, Schmidt et al. (1989)); however, groundnesting bees, unlike honey bees (Apis sp.), are capable of digesting this starchy food resource (Simpson 1983). Whilst combinations of additional pollen host species including Brugmansia candida, Solanum elaeagnifolium, Carya illinoensis, Quercus sp., Platanus racemose, Salvia sp. and Simmondsia chinense were successfully used to rear L. zephyrum previously (Roulston and Cane 2002), Typha pollen by itself constitutes a satisfactory diet for L. zephyrum (Greenberg 1982b). Additional anemophilous 
pollen host genera (e.g. Salix and Alnus) may also be suitable for rearing L. zephyrum and several other-ground-nesting species including L. imitatum, Augochlorella sp., N. fumipennis and H. rubicundus (Batra 1968). Greenberg (1982b) points out that attempts to rear species other than L. zephyrum in the lab are hindered by the fact many species will not utilise the readily available cattail (Typha) pollen and alternatives are unknown. Further research on host pollen preference in non-L. zephyrum bees will ultimately facilitate a greater understanding of the food provisioning needs required by species that will allow successful year-round rearing.

One important consideration when choosing which pollen host species to provide bees with includes pollen protein content. Offspring body size, a potentially important determinant of bee survival (Brand and Chapuisat 2012), increases by $25 \%$ in L. zephyrum when the protein content of pollen increases from 20 to $37 \%$ (Roulston and Cane 2002). Pollen protein content can be manipulated by adding pollen substitutes (e.g. soy flour pollen Dandt \& Co, Smith (1987)) or simply by providing pollen from different host pollen species varying in protein content (Roulston and Cane 2000). When using pollen substitutes, Greenberg (1982b) suggests a mixture of onefourth pollen and three-fourths pollen substitute for $L$. zephyrum . However, more conservative values (i.e. $<60 \%$ pollen substitute) may be more appropriate given significantly higher mortality (97\% vs. 31-38\%) was observed in L. zephyrum fed on a diet of $60 \%$ compared with $0-40 \%$ soy pollen substitute (Roulston and Cane 2002). Although bees generally prefer 'fresh' pollen over pollen substitutes (Greenberg 1982b), pollen substitution may be necessary given Typha typically only bloom for short periods (i.e. 2 weeks) during late spring (Krattinger 1975). To this end, pollen can be stored frozen, or dried and subsequently frozen until use (e.g. Platanus, Salvia and Simmondsia pollen were dried before storage by Roulston and Cane (2002)). When using pollen substitutes to increase protein content or extend food resources, researchers should be aware pollen substitutes decay quicker and require more frequent changing than 'fresh' pollen (i.e. daily replacement may be required).

\subsection{Insectary}

Alongside appropriate food provision, features of the insectary including photoperiod and temperature are important for maintaining active and reproductive nests (Kamm 1974; Greenberg 1982b). The photoperiod used by researchers has in the past ranged between 12- and 16-h light and 12- and 8-h dark. Whilst several studies maintain photoperiods similar to those encountered in summer (i.e. $\geq 15$-h light, Bell (1973), Bell et al. (1974)), or vary photoperiod over time (Plateaux-Quénu 1992; Plateaux-Quénu et al. 2000), photoperiods more closely simulating late spring and early autumn (i.e. 13.5-h light) may be more appropriate, especially when large individuals are preferred and/or colonies are to be maintained year-round (Greenberg 1982b). Lasioglossum zephyrum, for example, exhibits an inverse relationship between day length and cell size; 11 $(5.35+0.03-\mathrm{cm}$ cell diameter) compared with 13 $(5.22 \pm 0.8$-cm cell diameter $)$ and $15 \mathrm{~h}(5.22 \pm 0.8$ $\mathrm{cm}$ cell diameter) of day light leads to significantly larger cell widths, a factor positively correlated with adult size (Kamm 1974). Switching the lightdark cycle within the insectary may also facilitate nest maintenance and/or experimental manipulations where nest access is required (i.e. bees will be located inside the nest when it is accessed by researchers during the day) (personal communication, Quinn McFrederick).

Whilst temperature-related factors are a significant determinant of nest site quality in species including $H$. rubicundus (Potts and Willmer 1997), the effect of this factor on certain life history traits may be less clear. In L. zephyrum for example, temperature has no effect on worker rate (i.e. construction of new cells), in the temperature range of 21 to $30^{\circ} \mathrm{C}$, but does influence factors including development time, cell size and subsequent offspring size (Kamm 1974). Development time is significantly lower in L. zephyrum, when individuals are reared at $30{ }^{\circ} \mathrm{C}$ (males $18.3+0.71$ days and females $17.9 \pm 0.80$ days) compared with $21{ }^{\circ} \mathrm{C}$ (males $23.4+0.50$ days and females 23.8 \pm 0.27 days) (Kamm 1974). Head width (i.e. a proxy for total body size) in L. zephyrum is also inversely proportional to the temperature at which cells are constructed; nests maintained at lower 
temperatures (i.e. $21{ }^{\circ} \mathrm{C}$ ) contain larger L. zephyrum individuals (Kamm 1974). Offspring size is a key factor affecting individual mortality and ground-nesting bee colony success, with smaller females dying quicker, not developing readily and/or producing fewer offspring than field-caught individuals (Breed et al. 1978; Greenberg 1982b; Brand and Chapuisat 2012). As such, researchers should aim to maintain nests with large individuals. In L. zephyrum, this means rearing colonies under temperature regimes similar to those experienced in late spring and early autumn. Greenberg (1982b) advocates a daytime high of $28^{\circ} \mathrm{C}$ and night time low of $22^{\circ} \mathrm{C}$, and emphasises cooling at night as an important factor for maintaining colony vigour.

The simplest method for regulating temperature and humidity within an insectary involves using electric light bulbs and a damp towel, the most elaborate, an environmental chamber with programmed electronic controls for controlling temperature, humidity and photoperiod. Ultimately, the size of the insectary, alongside the specific question of interest, and whether the nest is open or closed will dictate the type of temperature and humidity control system required.

\section{CONCLUSIONS}

Whilst this review summarises factors relating to the construction and maintenance of artificial nests for ground-nesting bees, most studies cited here were conducted on a select few groundnesting species (i.e. mainly from the genus Lasioglossum ). Thus, moving forward, it is imperative we strive to tackle this species bias. Furthermore, the burden remains on researchers to provide detailed methodological information including how bees were collected in the field, what specific food resources were provided, and data relating to rearing temperature, humidity and light to dark cycle. In the same way trap-nesting methods continue to facilitate a greater understanding of the biology of certain apids and megachilids (MacIvor et al. 2017), artificial nests of ground-nesting bees will also facilitate a greater mechanistic understanding of the factors influencing life-history and ecological responses in important pollinating groups including ground-nesting groups.

\section{ACKNOWLEDGEMENTS}

The authors thank Jim Cane, Katja Hogendoorn, T'ai Roulston and Quinn McFrederick for advice regarding ground-nesting bee rearing and maintenance. The authors also thank Caitlyn Drayton-Taylor, Nick Anderson, Katie Barie, Scott Clem, Jon Tetlie, Anna Grommes and Benjamin Chiavini for feedback during manuscript preparation.

\section{AUTHORS CONTRIBUTION}

RJL and A.N.T-H conceived and wrote review. All authors read and approved the final manuscript.

\section{FUNDING INFORMATION}

Ryan J. Leonard is funded USAD NIFA 201867013-27537.

\section{COMPLIANCE WITH ETHICAL STANDARDS}

Conflict of interest The authors declare that they have no conflict of interest.

\begin{abstract}
Méthodes d'élevage d'abeilles nichant au sol dans des conditions de laboratoire
\end{abstract}

abeille nichant au sol / nid artificiel / élevage / Lasioglossum

Methoden zur Aufzucht von erdnistenden Bienen unter Laborbedingungen

Erdnistende Biene / künstliches Nest / Aufzucht / Lasioglossum

\section{REFERENCES}

Andrade-Silva, A., and F. Nascimento. (2012).Multifemale nests and social behavior in Euglossa melanotricha (Hymenoptera, Apidae, Euglossini). J. Hymenopt. Res. $26: 1-16$.

Barrows, E. M. (1975). Mating behavior in halictine bees (Hymenoptera: Halictidae): III. Copulatory behavior 
and olfactory communication. Insect. Soc. 22 (3):307331 .

Barrows, E. M. (1976). Mating behavior in halictine bees (Hymenoptera: Halictidae): II. Micro-territorial and patrolling behaviour in male male of Lasioglossum rohweri Insect. Soc. 40 (4):377-389.

Barrows, E. M., W. J. Bell, and C. D. Michener. (1975). Individual odor differences and their social functions in insects. PNAS 72 (7):2824-2828.

Batra, S. W. T. (1964). Behaviour of the social bee, Lasioglossum zephyrum, within the nest (Hymenoptera: Halictidae). Insect. Soc. 11 :159-186.

Batra, S. W. T. (1968). Behavior of some social and solitary halictine bees within their nests: a comparative study (Hymenoptera: Halictidae). J. Kansas Entomol. Soc. 41 (1):120-133.

Batra, S. W. T. (1970). Behavior of the alkali bee, Nomia melanderi, within the nest (Hymenoptera: Halictidae). Ann. Entomol. Soc. Am. 63 (2):400-406.

Batra, S. W. T. (1984). Solitary bees. SA 250 (2):120-127.

Bell, W. J. (1973). Factors controlling initiation of vitellogenesis in a primitively social bee, Lasioglossum zephyrum (Hymenoptera: Halictidae). Insect. Soc. 20 (3):253-260.

Bell, W. J., M. D. Breed, K. W. Richards, and C. D. Michener. (1974). Social, stimulatory and motivational factors involved in intraspecific nest defense of a primitively eusocial halictine bee. J. Comp. Physiol. 93 (3):173-181.

Bell, M. C., R. N. Spooner-hart, and A. M. Haigh. (2006). Pollination of greenhouse tomatoes by the Australian bluebanded bee Amegilla (Zonamegilla) holmesi (Hymenoptera: Apidae). J. Econ. Entomol. 99 (2):437442.

Boff, S., C. A. Saito, and I. A. Santos. (2017). Multiple aggressions among nestmates lead to weak dominance hampering primitively eusocial behaviour in an orchid bee. Sociobiology 64 (2):202-211.

Bohart, G. E. (1955). Time relationships in the nest construction and life cycle of the alkali bee. Ann. Entomol. Soc. Am. 48 (5):403-406.

Bosch, J., and W. Kemp. (2005). Alfalfa leafcutting bee population dynamics, flower availability, and pollination rates in two Oregon alfalfa fields. J. Econ. Entomol. 98 (4):1077-1086.

Brand, N., and M. Chapuisat. (2012). Born to be bee, fed to be worker? The caste system of a primitively eusocial insect. Front. Zool. 9 (1):35.

Breed, M. D., and G. J. Gamboa. (1977). Behavioral control of workers by queens in primitively eusocial bees. Science 195 (4279):694-696.

Breed, M. D., J. M. Silverman, and W. J. Bell. (1978). Agonistic behavior, social interactions, and behavioral specialization in a primitively eusocial bee. Insect. Soc. 25 (4):351-364.

Brothers, D. J., and C. D. Michener. (1974). Interactions in colonies of primitively social bees. J. Comp. Physiol. 90 (2):129-168.
Buckle, G. R. (1982). Queen-worker behavior and nesmate interactions in young colonies of Lasioglossum zephyrum. Insect. Soc. 29 (2):125-137.

Buckle, G. R. (1984). A second look at queen-forager interactions in the primitively eusocial halictid, Lasioglossum zephyrum. J. Kansas Entomol. Soc. $57(1): 1-6$.

Buckle, G. R., and L. Greenberg. (1981). Nestmate recognition in sweat bees (Lasioglossum zephyrum): does an individual recognize its own odour or only odours of its nestmates? Anim. Behav. 29 (3):802-809.

Bushmann, S. L., F. A. Drummond, L. A. Beers, and E. Groden. (2012). Wild bumblebee (Bombus) diversity and Nosema (Microsporidia: Nosematidae) infection levels associated with lowbush blueberry (Vaccinium angustifolium ) production and commercial bumblebee pollinators. Psyche (Camb Mass) 2012 : 429398.

Cameron, S., J. Whitfield, C. Hulslander, W. Cresko, S. Isenberg, and R. King. (1996). Nesting biology and foraging patterns of the solitary bee Melissodes rustica (Hymenoptera: Apidae) in northwest Arkansas. J. Kansas Entomol. Soc. 69 (4):260-273.

Cane, J. H. (1991). Soils of ground-nesting bees (Hymenoptera, Apoidea) - texture, moisture, cell depth and climate. J. Kansas Entomol. Soc. 64 (4):406-413.

Cane, J. H. (1997). Ground-nesting bees: the neglected pollinator resource for agriculture. Acta Hortic. 437 :309-324.

Cane, J. H. (2008). A native ground-nesting bee (Nomia melanderi) sustainably managed to pollinate alfalfa across an intensively agricultural landscape. Apidologie 39:315-323.

Cane, J. H. (2015). Landscaping pebbles attract nesting by the native ground-nesting bee Halictus rubicundus (Hymenoptera: Halictidae). Apidologie 46 :728-734.

Cane, J. H., and J. L. Neff. (2011). Predicted fates of ground-nesting bees in soil heated by wildfire: Thermal tolerances of life stages and a survey of nesting depths. Biol. Conserv. 144 (11):2631-2636.

Dalmazzo, M., and A. Roig-Alsina. (2012). Nest structure and notes on the social behavior of Augochlora amphitrite (Schrottky) (Hymenoptera, Halictidae). J. Hymenopt. Res. $26: 17-29$.

Dalmazzo, M., and A. Roig-Alsina. (2015). Social biology of Augochlora (Augochlora) phoemonoe (Hymenoptera, Halictidae) reared in laboratory nests. Insect. Soc. $62(3): 315-323$.

Danforth, B. N. (1991a). Female foraging and intranest behaviour of a communal bee, Perdita portalis (Hymeoptera, Andrenidae). Ann. Entomol. Soc. Am. 84 (5):537-548.

Danforth, B. N. (1991b). The morphology and behavior of dimorphic males in Perdita portalis (Hymenoptera : Andrenidae). Behav. Ecol. Sociobiol. 29 (4):235-247.

Davison, P., and J. Field. (2018a). Limited social plasticity in the socially polymorphic sweat bee Lasioglossum calceatum. Behav. Ecol. Sociobiol. 72 (3):56. 
Davison, P. J., and J. Field. (2018b). Environmental barriers to sociality in an obligate eusocial sweat bee. Insect. Soc. 65 (4):549-559.

Donovan, B. J., B. G. Howlett, and M. K. Walker. (2010). Relocation and establishment of nesting populations of the native bee Leioproctus huakiwi Donovan (Hymenoptera: Colletidae). N. Z. Entomol. 33 (1):109-113.

European Food Safety Authority. (2013). Guidance on the risk assessment of plant protection products on bees (Apis mellifera, Bombus spp. and solitary bees). EFSA J., 3295.

Forrest, J. R. K., and J. D. Thomson. (2011). An examination of synchrony between insect emergence and flowering in Rocky Mountain meadows. Ecol. Monogr. 81 (3):469-491.

Fortel, L., M. Henry, L. Guilbaud, H. Mouret, and B. E. Vaissière. (2016). Use of human-made nesting structures by wild bees in an urban environment. J. Insect Conserv. 20 (2):239-253.

Fründ, J., S. L. Zieger, and T. Tscharntke. (2013). Response diversity of wild bees to overwintering temperatures. Oecologia 173 (4):1639-1648.

Graham, J. R., Willcox, E., \& Ellis, J. D. (2015). The potential management of a ground-nesting, solitary bee: Anthophora abrupta (Hymenoptera: Apidae). Fla. Entomol. 98 (2):528-536.

Greenberg, L. (1982a). Persistent habituation to female odor by male sweat bees, (Lasioglossum zephyrum) (Hymenoptera: Halictidae). J. Kansas Entomol. Soc. 55 (3): 525-531.

Greenberg, L. (1982b). Year-round culturing and productivity of a sweat bee, Lasioglossum zephyrum (Hymenoptera, Halictidae). J. Kansas Entomol. Soc. $55(1): 13-22$.

Greenberg, L., and G. R. Buckle. (1981). Inhibition of worker mating by queens in a sweat bee, Lasioglossum zephyrum. Insect. Soc. 28 (4):347-352.

Grundel, R., R. P. Jean, K. J. Frohnapple, G. A. Glowacki, P. E. Scott, and N. B. Pavlovic. (2010). Floral and nesting resources, habitat structure, and fire influence bee distribution across an open-forest gradient. Ecol. Appl. 20 (6):1678-1692.

Hartman, C. G. (1943). A glass-tube method for oberving the home life of solitary bees and wasps. Sch. Sci. Math. 43 (8):709-711.

Hogendoorn, K., C. L. Gross, M. Sedgley, and M. A. Keller. (2006). Increased tomato yield through pollination by native Australian Amegilla chlorocyanea (Hymenoptera: Anthophoridae). J. Econ. Entomol. 99 (3):828-833.

Holbrook, C. T., R. M. Clark, R. Jeanson, S. M. Bertram, P. F. Kukuk, and J. H. Fewell. (2009). Emergence and consequences of division of labor in associations of normally solitary sweat bees. Ethology 115(4):301310.

Holbrook, C. T., P. F. Kukuk, and J. H. Fewell. (2013). Increased group size promotes task specialization in a normally solitary halictine bee. Behaviour 150 (12):1449-1466.
Jeanson, R., P. F. Kukuk, and J. H. Fewell. (2005). Emergence of division of labour in halictine bees: contributions of social interactions and behavioural variance. Anim. Behav. 70 (5):1183-1193.

Jeanson, R., R. M. Clark, C. T. Holbrook, S. M. Bertram, J. H. Fewell, and P. F. Kukuk. (2008). Division of labour and socially induced changes in response thresholds in associations of solitary halictine bees. Anim. Behav. 76(3):593-602.

Johansen, C., D. Mayer, H. Homan, and J. Capizz. (1976). Alkali bees: their biology and management for alfalfa seed production in the Pacific Northwest. Publication, Pacific Northwest Cooperative Extension Service No. PNW.

Kamm, D. R. (1974). Effects of temperature, day length, and number of adults on the sizes of cells and offspring in a primitively social bee (Hymenoptera: Halictidae). J. Kansas Entomol. Soc. 47 (1):8-18.

Kapheim, K. M., and M. M. Johnson. (2017). Juvenile hormone, but not nutrition or social cues, affects reproductive maturation in solitary alkali bees (Nomia melanderi ). J. Exp. Biol. 220 (20):3794-3801.

Kearns, C. A., and D. M. Oliveras. (2009). Environmental factors affecting bee diversity in urban and remote grassland plots in Boulder, ColoradoJ. Insect Conserv. 13 (6):655-665.

Kim, J., N. Williams, and C. Kremen. (2006). Effects of cultivation and proximity to natural habitat on groundnesting native bees in California sunflower fields. J. Kansas Entomol. Soc. 79(4):309-320.

Kopit, A. M., and T. L. Pitts-Singer. (2018). Routes of Pesticide Exposure in Solitary, Cavity-Nesting Bees. Environ. Entomol. 47 (3):499-510.

Kratschmer, S., B. Pachinger, M. Schwantzer, D. Paredes, M. Guernion, F. Burel, A. Nicolai, P. Strauss, T. Bauer, and M. Kriechbaum. (2018). Tillage intensity or landscape features: what matters most for wild bee diversity in vineyards? Agric. Ecosyst. Environ. 266 :142152.

Krattinger, K. (1975). Genetic mobility in Typha. Aquat. Bot. $1: 57-70$.

Kritsky, G. (2010). The quest for the perfect hive: a history of innovation in bee culture. Oxford University Press.

Kukuk, P. F., and R. H. Crozier. (1990). Trophallaxis in a communal halictine bee Lasioglossum (Chilalictus) erythrurum. PNAS 87(14):5402-5404.

Kukuk, P. F., and P. C. Decelles. (1986). Behavioral evidence for population structure in Lasioglossum (Dialictus) zephyrum female dispersion patterns. Behav. Ecol. Sociobiol. 19 (4):233-239.

Kukuk, P. F., and B. May. (1991). Colony dynamics in a primitavely eusocial Halictine bee Lasioglossum (Dialictus) zephyrum (Hymenoptera, Halictidae). Insect. Soc. $38(2): 171-189$.

Kukuk, P. F., and M. Schwarz. (1987). Intranest behavior of the communal sweat bee Lasioglossum (Chilalictus) erythrurum (Hymenoptera: Halictidae). J. Kansas Entomol. Soc. 60 (1):58-64. 
Kukuk, P. F., M. D. Breed, S. Anita, and W. J. Bell. (1977). The contributions of kinship and conditioning to nest recognition and colony member recognition in a primitively eusocial bee, Lasioglossum zephyrum (Hymenoptera: Halictidae). Behav. Ecol. Sociobiol. $2(3): 319-327$.

Kumar, S. (1975). Relations among Bee Size, Cell Size, and Caste, in Lasioglossum zephyrum (Hymenoptera, Halictidae). J. Kansas Entomol. Soc. 48(3):374-380.

Linsley, E. G., J. W. MacSwain, and R. F. Smith. (1952). Outline for ecological life histories of solitary and semi-social bees. Ecology 33 (4):558-567.

MacIvor, J. S. (2017). Cavity-nest boxes for solitary bees: a century of design and research. Apidologie 48 (3):311327.

MacIvor, J. S., and L. Packer. (2015). 'Bee hotels' as tools for native pollinator conservation: a premature verdict? PLoS One 10 (3):e0122126.

Malyshev, S. (1925). The nesting habits of Anthophora Latr. Trudy leningrObshch. Estest $55: 137-183$.

Marinho, D., J. Andrade, R. O. Araujo, and F. Vivallo. (2018). A new technique in the excavation of ground-nest bee burrows (Hymenoptera: Apoidea). Rev. Bras. Entomol. 62 (1):1-4.

Martins, R. P., S. T. M. Guerra, and M. S. Barbeitos. (2001). Variability in egg-to-adult development time in the bee Ptilothrix plumata and its parasitoids. Ecol. Entomol. $26: 609-616$.

Martins, C. F., M. P. Peixoto, and C. M. L. Aguiar. (2014). Plastic nesting behavior of Centris (Centris) flavifrons (Hymenoptera: Apidae: Centridini) in an urban area. Apidologie 45 (2):156-171.

McFrederick, Q. S., and D. R. Taylor. (2013). Evolutionary history of nematodes associated with sweat bees. Mol. Phylogenet. Evol. 66 (3):847-856.

Michener, C. D. (1966). The bionomics of a primitively social bee, Lasioglossum versatum (Hymenoptera: Halictidae). J. Kansas Entomol. Soc. 39 (2):193-217.

Michener, C. D. (1974). The social behavior of the bees: a comparative study. Harvard University Press.

Michener, C. D. (2000). The bees of the world. JHU press.

Michener, C. D., and D. J. Brothers. (1971). A simplified observation nest for burrowing bees. J. Kansas Entomol. Soc. 44 (2):236-239.

Michener, C. D., and D. J. Brothers. (1974). Were workers of eusocial Hymenoptera initially altruistic or oppressed? PNAS 71 (3):671-674.

Michener, C. D., E. A. Cross, H. V. Daly, C. W. Rettenmeyer, and A. Wille. (1955). Additional techniques for studying the behavior of wild bees. Insect. Soc. 2 (3):237-246.

Michener, C. D., D. J. Brothers, and D. R. Kamm. (1971). Interactions in colonies of primitively social bees: II, some queen-worker relations in Lasioglossum zephyrum. J. Kansas Entomol. Soc. 44 (2):276-279.

Moroń, D., I. M. Grześ, P. Skórka, H. Szentgyörgyi, R. Laskowski, S. G. Potts, and M. Woyciechowski.
(2012). Abundance and diversity of wild bees along gradients of heavy metal pollution. J. Appl. Ecol. 49 (1):118-125.

Mueller, U. G., and B. Wolf-Mueller. (1993). A method for estimating the age of bees: Age-dependent wing wear and coloration in the Wool-Carder bee Anthidium manicatum (hymenoptera: Megachilidae). J. Insect Behav. 6(4):529-537.

Norden, B.B. (1984). Nesting biology of Anthophora abrupta (Hymenoptera: Anthophoridae). J. Kansas Entomol. Soc. 57 (2):243-262.

Parker, F. D., and H. W. Potter. (1974). Methods of transferring and establishing Alkali bees. Environ. Entomol. 3 (5):739-743.

Paxton, R. J., M. Ayasse, J. Field, and A. Soro. (2002). Complex sociogenetic organization and reproductive skew in a primitively eusocial sweat bee, Lasioglossum malachurum, as revealed by microsatellites. Mol. Ecol. 11 (11):2405-2416.

Plateaux-Quénu, C. (1992). Comparative biological data in two closely related eusocial species: Evylaeus calceatus (Scop.) and Evylaeus albipes (F.) (Hym., Halictinae). Insect. Soc. 39 (4):351-364.

Plateaux-Quénu, C., L. Plateaux, and L. Packer. (2000). Population-typical behaviours are retained when eusocial and non-eusocial forms of Evylaeus albipes (F.) (Hymenoptera, Halictidae) are reared simultaneously in the laboratory. Insect. Soc. 47 (3):263-270.

Polidori, C., and L. Borruso. (2012). Socially peaceful: foragers of the eusocial bee Lasioglossum malachurum are not aggressive against nonnestmates in circle-tube arenas. Acta Ethol. $15(1): 15-23$.

Potts, S., and P. Willmer. (1997). Abiotic and biotic factors influencing nest-site selection by Halictus rubicundus, a ground-nesting halictine bee. Ecol. Entomol. $22(3): 319-328$.

Praz, C. J., A. Müller, and S. Dorn. (2008). Host recognition in a pollen-specialist bee: evidence for a genetic basis. Apidologie 39 (5):547-557.

Roulston, T. H., and J. H. Cane. (2000). Pollen nutritional content and digestibility for animals. Plant Syst. Evol. $222(1-4): 187-209$.

Roulston, T. H., and J. H. Cane. (2002). The effect of pollen protein concentration on body size in the sweat bee Lasioglossum zephyrum (Hymenoptera : Apiformes). Evol. Ecol. 16(1):49-65.

Rozen, J. G. (2016). Nesting biology of the solitary bee Epicharis albofasciata (Apoidea: Apidae: Centridini). Am. Mus. Novit. $3869: 1-8$.

Ruddle, N., C. Elston, O. Klein, A. Hamberger, and H. Thompson. (2018). Effects of exposure to winter oilseed rape grown from thiamethoxam-treated seed on the red mason bee Osmia bicornis . Environ. Toxicol. Chem. 37 (4):1071-1083.

Schäffler, I., and S. Dötterl. (2011). A day in the life of an oil bee: phenology, nesting, and foraging behavior. Apidologie 42 (3):409-424. 
Schmidt, J. O., S. L. Buchmann, and M. Glaiim. (1989). The nutritional value of Typha latifolia pollen for bees. J. Apic. Res. 28(3):155-165.

Shebl, M. A., R. M. Al Aser, and A. Ibrahim. (2016). Nesting biology and seasonality of long-horned bee Eucera nigrilabris Lepeletier (Hymenoptera: Apidae). Sociobiology 63 (4):1031-1037.

Sick, M., M. Ayasse, J. Tengö, W. Engels, G. Lübke, and W. Francke. (1994). Host-parasite relationships in six species of Sphecodes bees and their halictid hosts: Nest intrusion, intranidal behavior, and Dufour's gland volatiles (Hymenoptera: Halictidae). J. Insect Behav. 7 (1):101-117.

Simpson, B. (1983). Evolution and diversity of floral rewards. Handbook of experimental pollination biology. 142-159.

Smith, B. H. (1987). Effects of genealogical relationship and colony age on the dominance hierarchy in the primitively eusocial bee Lasioglossum zephyrum . Anim. Behav. 35(1):211-217.

Staab, M., G. Pufal, T. Tscharntke, and A. M. Klein. (2018). Trap nests for bees and wasps to analyse trophic interactions in changing environments - A systematic overview and user guide. Methods Ecol. Evol. 9 (11):22262239.

Stephen, W. P. (1960a). Artificial bee beds for the propagation of the Alkali bee, Nomia melander. J. Econ. Entomol. 53 (6):1025-1030.

Stephen, W. P. (1960b). Studies in the alkali bee (Nomia melanderi Ckll.) II. Preliminary investigations on the effect of soluble salts on alkali bee nesting sites. Agricultural Experiment Station, Oregon State College, Corvallis, Oregon.
Stephen, W. P. (1965). Effects of soil moisture on survival of prepupae of the alkali bee. J. Econ. Entomol. $58(3): 472-474$.

Stockhammer, K. A. (1966). Nesting habits and life cycle of a sweat bee, Augochlora pura (Hymenoptera: Halictidae). J. Kansas Entomol. Soc. 39 (2):157-192.

Strohm, E., and A. Bordon-Hauser. (2003). Advantages and disadvantages of large colony size in a halictid bee: the queen's perspective. Behav. Ecol. 14(4):546553.

Ullmann, K. S., M. H. Meisner, and N. M. Williams. (2016). Impact of tillage on the crop pollinating, ground-nesting bee, Peponapis pruinosa in CaliforniaAgric. Ecosyst. Environ. 232 :240-246.

Vinchesi, A. C., and D. B. Walsh. (2014). Quadrat method for assessing the population abundance of a commercially managed native soil-nesting bee, Nomia melanderi (Hymenoptera: Halictidae), in proximity to alfalfa seed production in the Western United States. J. Econ. Entomol. 107 (4):1695-1699.

Wcislo, W. T. (1992). Attraction and learning in matefinding by solitary bees, Lasioglossum (Dialictus) figueresi Wcislo and Nomia triangulifera Vachal (Hymenoptera: Halictidae). Behav. Ecol. Sociobiol. 31 (2):139-148.

Yanega, D. (1990). Philopatry and nest founding in a primitively social bee, Halictus rubicundus. Behav. Ecol. Sociobiol. 27 (1):37-42.

Publisher's note Springer Nature remains neutral with regard to jurisdictional claims in published maps and institutional affiliations. 